\title{
PENGEMBANGAN MODEL PENILAIAN KETERAMPILAN INTRAPRIBADI DAN ANTARPRIBADI DALAM PENDIDIKAN KARAKTER DI SEKOLAH DASAR
}

\author{
1) Akif Khilmiyah, ${ }^{2)}$ Sumarno, ${ }^{3)}$ Darmiyati Zuchdi \\ ${ }^{1}$ Universitas Muhammadiyah Yogyakarta, ${ }^{2,3}$ Universitas Negeri Yogyakarta \\ ${ }^{1)}$ khilmiyahakif@yahoo.com, ${ }^{2)}$ sumarno_unj@yahoo.co.uk, ${ }^{33}$ darmiyati@uny.ac.id
}

\begin{abstract}
Abstrak
Penelitian ini bertujuan untuk mengembangkan model penilaian keterampilan intrapribadi dan antarpribadi dalam pendidikan karakter di SD yang valid, reliabel, dan cocok secara statistik. Penelitian ini menggunakan model research and development dari Plomp dengan lima fase, yaitu: investigasi, desain, realisasi, tes, dan implementasi. Subjek penelitian yaitu siswa kelas V SD di DI Yogyakarta. Pengumpulan data menggunakan kuesioner, dokumentasi, wawancara, FGD, dan observasi. Analisis data menggunakan analisis deskriptif, formula Aiken's $V$, EFA dan $C F A$. Simpulan penelitian ini yaitu konstruk penilaian keterampilan intrapribadi dan antarpribadi dalam pendidikan karakter telah memenuhi syarat validitas, reliabilitas, dan goodness of fit statistic; dan panduan penilaian keterampilan intrapribadi dan antarpribadi dalam pendidikan karakter di SD dinilai komprehensif, mudah, dan praktis oleh para guru selaku pengguna.
\end{abstract}

Kata kunci: keterampilan intrapribadi, keterampilan antarpribadi, pendidikan karakter.

\section{DEVELOPING OF ASSESSMENT MODEL OF INTRAPERSONAL AND INTERPERSONAL SKILLS BASED ON CHARACTER EDUCATION IN ELEMENTARY SCHOOLS}

\author{
1) Akif Kbilmiyah, ${ }^{2)}$ Sumarno, ${ }^{3)}$ Darmiyati Zuchdi \\ ${ }^{1)}$ Universitas Muhammadiyah Yogyakarta, ${ }^{2,3}$ Universitas Negeri Yogyakarta \\ 1)khilmiyahakif@yahoo.com, ${ }^{2)}$ sumarno_unj@yahoo.co.uk, ${ }^{3)}$ darmiyati@uny.ac.id
}

\begin{abstract}
The objectives of this study is to develop the assessment model of intrapersonal and interpersonal skills in character education of elementary school students that fit into the criteria of validity, reliability and goodness of fit statistic. This study used plomp's research and development model which consisted of five phases, namely: investigation, design, realization, testing, and implementation. The subjects of this study were the fifth grade students of the elementary schools in Yogyakarta Special Region. The data were collected using a questionnaire, documentation, interview, focus group discussion, and observation, and analyzed using the descriptive analysis, formula aiken's V, Exploratory FactorAnalysis (EFA), and Confirmatory Factor Analysis (CFA). The results of this study are as follows, (1) the assessment construct of intrapersonal and interpersonal skills based on character education for elementary school students has fulfilled the criteria of validity, reliability, and the goodness of fit statistic.
\end{abstract}

Keywords: intrapersonal skills, interpersonal skills, character education 


\section{Pendahuluan}

Tujuan sekolah dalam mendidik karakter adalah agar siswa menjadi pribadi yang unggul secara menyeluruh, yakni pribadi yang cerdas secara intelektual, emosional, sosial, dan spiritual. Penanaman pendidikan karakter ini harus dimulai dari jenjang pendidikan yang paling rendah yakni Sekolah Dasar (SD). Pada jenjang SD, anakanak masih bisa dibentuk dengan mudah dan diperkenalkan dengan berbagai karakter positif, agar tumbuh menjadi pribadi yang memiliki pola pikir yang baik, kemauan baik, dan perilaku yang baik sebagai bekal kelak dalam mengarungi kehidupan. Pembentukan pribadi yang unggul secara menyeluruh ini, telah tercantum dalam pasal 3, UU nomor 20/2003 tentang Sistem Pendidikan Nasional (Kemendiknas, 2011, p.243). Tujuan untuk membentuk pribadi yang memiliki kecerdasan secara menyeluruh ini, selaras dengan Permendiknas nomor 22 dan 23/2006 tentang Standar Isi dan SKL, Inpres nomor 1/2010, tentang Percepatan Pelaksanaan Prioritas Pembangunan Nasional Tahun 2010 yang memerintahkan perlunya pengembangan karakter peserta didik melalui pendidikan di sekolah.

Namun, berdasarkan survei peneliti pada beberapa SD di Yogyakarta, ditemukan fakta bahwa 70\% kecerdasan dan penilaian yang banyak dikembangkan di SD adalah kecerdasan intelektual melalui penilaian kognitif. Perhatian dan pemahaman para guru akan pentingnya pengembangan kecerdasan emosional, sosial, dan spiritual masih sangat rendah dalam proses pembelajaran dan penilaian. Penilaian tentang karakter siswa hanya didasarkan pada pengamatan guru selama di sekolah saja. Penilaian khusus tentang keterampilan intrapribadi dan antarpribadi di SD belum ada. Model penilaian yang digunakan juga bervariasi dan biasanya dikembangkan sendiri oleh guru agama. Kebanyakan guru beranggapan bahwa pembentukan karakter dan akhlak siswa lebih dekat dengan muatan materi pelajaran agama.

Hal ini didukung pula oleh hasil penelitian Zuchdi (2010, p.68), bahwa praktik penilaian hasil belajar di sekolah, khususnya di SD, sarat dengan penilaian kognitif semata. Penghargaan pada siswa ditunjukkan guru melalui pemberian ranking dan nilai ujian. Meskipun semua pendidik tahu bahwa ranah pendidikan itu ada kognitif, afektif, dan psikomotor (perilaku), namun pada praktiknya penilaian ranah afektif dan psikomotor (perilaku) belum mendapat porsi perhatian yang memadai. Kondisi ini terjadi karena kurangnya kemampuan pendidik untuk mendeskripsikan indikator capaian ranah afektif, sehingga penilaian yang dilakukan kepada siswa tidak menggambarkan kemampuan siswa secara me-nyeluruh. Akibatnya pendidik tidak mampu melakukan pembinaan aspek afektif yang meliputi kecerdasan emosional, sosial, dan spiritual, yang termanifestasikan dalam keterampilan intrapribadi (intrapersonal) dan antarpribadi (interpersonal). Padahal kedua keterampilan ini merupakan inti dari pendidikan karakter yang harus dimiliki siswa, sebagai hasil dari proses pembelajaran di sekolah.

Pentingnya pendidikan karakter yang termanifestasikan dalam keterampilan intrapribadi dan antarpribadi memberikan pengaruh yang besar pada kesuksesan seseorang dalam kehidupan. Hal itu, sebagaimana hasil penelitian Goleman (1995, p.15), Gardner (1996, p.26), dan Bar-On (1988, p.24; 1997, p.123; 2000, p.46; 2005, p.94), Berkowitz, (2002, p.23) yang menemukan bahwa $80 \%$ penentu kesuksesan seseorang adalah kecerdasan emosional. Demikian pula hal itu sesuai dengan hasil penelitian Zamroni, yang menemukan bahwa 70\% orang sukses dalam kehidupannya bukan karena kecerdasan intelektual dan vokasional, tetapi justru karena kecerdasan generik (2005, p.49). Kemampuan generik ini ditunjukkan melalui: (1) kemampuan personal (kemampuan mengambil keputusan secara rasional, kemampuan merancang masa depan, dll), (2) kemampuan sosial (kemampuan bekerja sama, kemampuan memahami orang lain, dll).

Hal ini diperkuat pula dari hasil penelitian pendahuluan yang dilakukan oleh peneliti pada SD yang menjadi piloting pen- 
didikan karakter di Bantul, tahun 2011 dan 2012 diperoleh kesimpulan bahwa 80\% siswa mengalami permasalahan rendahnya keterampilan intrapribadi yang terlihat dari rendahnya sikap kejujuran, rasa percaya diri, dan kemandirian. Sebanyak 78\% siswa mengalami rendahnya keterampilan antarpribadi yang ditunjukkan dengan rendahnya sikap kerja sama, tanggung jawab, kemampuan mengatasi konflik, dan rendahnya sikap toleransi antarsiswa (Khilmiyah,2011, p.65; 2012, p.62). Kondisi ini menunjukkan masih rendahnya keterampilan intrapribadi dan antarpribadi siswa SD dalam mengelola emosi diri sendiri dan kemampuan bersosialisasi dengan orang lain, yang berdampak pada munculnya sikap apatis, egois, dan inferior. Padahal menurut Zuchdi, (2010, p.69) keterampilan intrapribadi dan antarpribadi dapat mempengaruhi perkembangan kepribadian ke arah positif. Pengaruh positif tersebut antara lain berwujud dalam bentuk dapat menghargai orang lain, mampu menemukan alternatif pemecahan masalah, kreatif, sabar, dan mandiri.

Untuk mewujudkan pribadi siswa yang memiliki karakter terpuji, maka guru perlu melakukan penilaian keterampilan intrapribadi dan antarpribadi secara periodik agar diperoleh informasi lebih awal tingkat kekurangan capaian kemampuan karakter siswa yang harus segera dibenahi. Melalui penilaian karakter yang komprehensif, diharapkan guru mampu mengembangkan potensi siswa secara utuh, yang meliputi kemampuan intelektual ataupun kemampuan emosional, sosial, dan spiritual.

Berdasarkan uraian tersebut, maka penelitian ini dipandang penting dan strategis untuk dilakukan guna mengembangkan model penilaian keterampilan intrapribadi dan antarpribadi. Hasil penelitian ini dapat dimanfaatkan oleh guru untuk meningkatkan karakter siswa yang termanifestasikan dalam kecerdasan emosional, sosial, dan spiritual, karena selama ini belum tersedia acuan kriteria model penilaiannya.

Permasalahan penelitian ini terfokus pada tiga hal yakni: (1) mengkaji sejauhmana kelemahan model penilaian yang se- lama ini digunakan untuk mendeteksi capaian pendidikan karakter di SD; (2) bagaimana mengembangkan model penilaian keterampilan intrapribadi dan antarpribadi dalam pendidikan karakter di SD yang komprehensif dan memenuhi kriteria valid, reliabel, dan goodness of fit statistic; (3) bagaimana mengembangkan panduan model Penilaian Keterampilan Intrapribadi dan Antarpribadi dalam pendidikan karakter di SD (PKIASD) yang komprehensif.

Tujuan penelitian ini adalah (1) untuk mengidentifikasi kelemahan model penilaian yang selama ini digunakan untuk mendeteksi capaian pendidikan karakter di SD; (2) untuk mengembangkan model penilaian keterampilan intrapribadi dan antarpribadi dalam pendidikan karakter di SD yang komprehenshif dan memenuhi kriteria valid, reliabel, dan goodness of fit statistic; dan (3) untuk mengembangkan panduan model Penilaian Keterampilan Intrapribadi dan Antarpribadi dalam pendidikan karakter di SD (PKIA-SD) yang komprehensif.

Secara teoretis, temuan pengembangan model PKIA-SD ini dapat dijadikan rujukan untuk mengembangkan model penilaian kepribadian anak, pada aspek nilainilai pendidikan karakter yang lain secara lebih mendalam. Secara metodologis, hasil penelitian ini dapat dijadikan rujukan untuk pengembangan model penilaian keterampilan intrapribadi dan antarpribadi pada siswa SD tingkat rendah (kelas 1-3). Secara praktis, temuan penelitian ini dapat dipakai oleh guru kelas di SD tingkat tinggi (kelas 4-6), untuk melakukan penilaian capaian keterampilan intrapribadi dan antarpribadi dalam rangka melaksanakan pendidikan karakter, sehingga guru dapat melakukan pembinaan karakter lebih awal. Bagi pembuat kebijakan, khususnya penentu kebijakan terkait dengan pelaksanaan karakter dan akhlak mulia di SD/ MI, temuan penelitian ini dapat dijadikan model pembinaan kepada para guru SD/MI untuk melakukan penilaian capaian keterampilan intrapribadi dan antarpribadi dalam pelaksanaan pendidikan karakter secara komprehensif, yang mencakup ranah kognitif, afektif, dan psikomotorik. 


\section{Metode Penelitian}

Jenis penelitian ini yaitu research and development dengan menggunakan model Plomp. Model ini terdiri dari lima fase, yaitu: investigasi, desain, realisasi, tes, dan im-plementasi (1997, p.5).

Penelitian ini dilaksanakan selama satu tahun mulai bulan Juni 2013. Tempat penelitiannya yaitu di Sekolah Dasar (SD) yang ada di Daerah Istimewa Yogyakarta (DIY).

Subjek penelitian ini adalah siswa kelas V SD di satu kota, dan tiga kabupaten di DIY. Jumlah subjek uji coba secara akumulatif sebanyak 518 siswa, yang terdiri dari subjek uji coba terbatas sebanyak 54 siswa dari 2 SD, dan subjek uji coba diperluas sebanyak 464 siswa dari 15 SD.

Pemilihan subjek uji coba penelitian ini dilakukan secara purposive sampling yang didasarkan pada pertimbangan usia anak (10-12 tahun) dan kemampuan melakukan penalaran moral secara otonom. Selain itu, dipertimbangkan berdasarkan variasi SD pada aspek: (1) perbedaan penerapan budaya pendidikan karakter di SD, (2) perbedaan sebagai SD piloting pendidikan karakter, (3) perbedaan agama, (4) perbedaan lama waktu belajar di sekolah, (5) perbedaan program pendidikan karakter di sekolah. Berdasarkan kriteria tersebut, dipilih subjek uji coba yang meliputi: 4 SD Negeri piloting pendidikan karakter dari Dinas Dikpora DIY, 2 SD Negeri bukan piloting pendidikan karakter, 1 SD Swasta bercorak kebangsaan, 4 SD Swasta berbasis Islam, 2 SD Swasta berbasis Katholik, 2 SD IT yang menerapkan fullday school, 2 MI Negeri dan Swasta yang berada dalam pembinaan Kemenag RI.

Penelitian dan pengembangan ini dilakukan dalam dua tahap kegiatan, yaitu tahap prapengembangan dan tahap pengembangan. Kegiatan prapengembangan model PKIA-SD terdiri dari tiga tahap yaitu tahap investigasi, tahap desain, dan tahap realisasi. Tahap investigasi yaitu mengidentifikasi kelemahan model penilaian pendidikan karakter di SD dan mengkaji kebutuhan model PKIA-SD bagi guru dan siswa. Tahap desain yaitu kegiatan-kegiatan yang dilakukan oleh peneliti dalam merancang perangkat model PKIA-SD, meliputi: merumuskan konstruk teori, mengembangkan indikator, mendeskripsikan indikator, menyusun item instrumen. Tahap realisasi terdiri dari kegiatan validasi melalui pakar dan praktisi, membuktikan validitas dan reliabilitas empirik, evaluasi hasil uji coba, revisi, membuktikan validitas dan estimasi reliabilitas konstruk model PKIA-SD.

Data kuantitatif diperoleh dari angket semi terbuka, sedangkan data kualitatif diperoleh dari hasil FGD, wawancara, dan observasi. Pengumpulan data melalui teknik dokumentasi, wawancara, observasi, FGD (Focus Group Discussion), dan kuesioner. Instrumennya berupa dokumen software dan hardware, pedoman wawancara, lembar pengamatan, dan angket semi terbuka.

Penelitian ini menggunakan analisis deskriptif kuantitatif dan kualitatif untuk mendeskripsikan data capaian keterampilan intrapribadi dan antarpribadi. Formula Aiken's $V$, dipakai untuk membuktikan validitas isi. Analisis metode Cronbach's Alpha, digunakan untuk mengetahui tingkat reliabilitas instrumen. Teknik Exploratory Factor Analysis (EFA), digunakan untuk mengetahui nilai eigenvalue yang terbentuk menjadi faktor atau dimensi dari variabel laten. Teknik analisis faktor konfirmatori orde dua (Second Order Confirmatory Factor Analysis) digunakan untuk menguji kecocokan model PKIA-SD (Joreskog \& Sorbon, 1999, p.115).

\section{Hasil Penelitian dan Pembahasan}

\section{Hasil Penelitian}

Hasil investigasi awal yang dilakukan selama tiga bulan pada 17 SD di DIY, ditemukan adanya perbedaan variasi penerapan budaya pendidikan karakter pada masing-masing sekolah. Ada 7 macam variasi penerapan budaya pendidikan karakter di SD, sehingga ada 7 jenis SD, yaitu: (1) SD Negeri yang menjadi piloting pendidikan karakter, (2) SD Negeri yang bukan piloting pendidikan karakter, (3) SD Swasta berbasis Islam, (4) SD Swasta berbasis Katholik, (5) 
SD swasta berbasis kebangsaan, (6) SDIT yang menerapkan full day school, dan (7) MI di bawah Kementerian Agama.

Hasil yang diperoleh dari investigasi awal ini, antara lain: model penerapan pendidikan karakter di SD dilaksanakan melalui empat model yakni: (1) pembelajaran di kelas, (2) pembiasaan rutin dalam kegiatan sekolah, (3) keteladanan dalam menjaga ketertiban, dan (4) kegiatan keagamaan.

Evaluasi praktek penilaian karakter di SD dilaksanakan dengan dua model penilaian yakni: (1) model evaluasi perilaku, dan (2) model monitoring akhlak yang dilakukan oleh guru PAI. Kedua model penilaian mengandung kelemahan sebagai berikut: penilaiannya bersifat mekanik, penilaiannya tidak menyeluruh, hanya aspek perilaku saja. Hasil penilaian belum menyentuh keterampilan yang dibutuhkan untuk memperkuat kepribadian siswa, dan siswa tidak dilibatkan untuk menilai sendiri penalaran dan perasaan moral yang dimilikinya.

Hasil analisis kebutuhan menunjukkan adanya kebutuhan yang dirasakan guru tentang pentingnya buku panduan penilaian keterampilan intrapribadi dan antarpribadi dalam pendidikan karakter untuk siswa SD. Panduan ini dapat dijadikan sebagai pedoman baku bagi para guru untuk untuk menilai keterampilan intrapribadi dan antarpribadi siswa sebagai keterampilan softskills yang perlu dikuasai oleh siswa sebagai bekal untuk memperoleh kesuksesan hidup.

Hasil Pembahasan

\section{Desain kisi-kisi instrumen model PKLA-SD}

Untuk mendesain kisi-kisi instrumen model PKIA-SD diawali dengan perumusan definisi konseptual keterampilan intrapribadi dan antarpribadi. Keterampilan intrapribadi didefinisikan sebagai kemampuan individu dalam mengenali, menghargai, mengelola, mengendalikan perasaan diri, dan merasakan realita spiritualitas diri untuk memahami keberadaan diri dan berani bertanggung jawab terhadap kehidupan pribadi, sehingga terbentuk kepribadian berakhlak mulia. Definisi ini dirumuskan sebagai hasil sintesis lima konsep teori keterampilan intrapribadi dari pendapat Gardner (1993, p.24-25), Lazear (2000, p.24), Bar-On (1997b, p.120), Lwin. (2005, p.233), dan Amin (1974, p.61).

Keterampilan antarpribadi didefinisikan sebagai kemampuan untuk menghargai pandangan orang lain, menyadari tanggung jawab sosial, bekerja sama, tenggang rasa, dan mampu berkomunikasi dengan orang lain. Definisi ini sebagai hasil sintesis lima konsep teori keterampilan antarpribadi yang berasal dari pendapat Gardner (1993, p.240), Bar-On (1997b, p.161), Lazear (2000, p.23), Mant (1997, p.161), dan Cunningham \& Corderio (2003, p.205).

Berdasarkan definisi konseptual tersebut dapat dirumuskan indikator-indikator dari keterampilan intrapribadi dan keterampilan antarpribadi. Keterampilan intrapribadi mempunyai lima indikator, yaitu: (1) mengenali perasaan diri sendiri, (2) menghargai perasaan diri sendiri, (3) mengelola perasaan diri sendiri, (4) mengendalikan perasaan diri sendiri, dan (5) merasakan realita spiritualitas diri sendiri. Sedangkan keterampilan antarpribadi mempunyai lima indikator, yaitu: (1) menghargai pandangan orang lain, (2) menyadari tanggung jawab sosial, (3) bekerja sama dengan orang lain, (4) tenggang rasa terhadap orang lain, dan (5) berkomunikasi secara efektif dengan orang lain.

Berdasarkan indikator tersebut disusunlah kisi-kisi instrumen model PKIA-SD yang dibagi dalam tiga ranah penilaian keterampilan intrapribadi dan antarpribadi dalam pendidikan karakter, yaitu kognitif, afektif, dan psikomotor.

\section{Desain model PKIA-SD}

Model PKIA-SD yang dikembangkan dalam penelitian ini berupa seperangkat pengukuran nontes yang terdiri atas 3 jenis model penilaian untuk menilai keterampilan intrapribadi dan antarpribadi. Adapun ketiga jenis penilaian dalam model PKIA-SD sebagai berikut. 
Model penilaian keterampilan intrapribadi dan antarpribadi pada aspek kognitif disingkat INTRAKOG dan ANTARKOG

Model penilaian ini digunakan untuk mengetahui tahapan penalaran moral siswa tentang keterampilan intrapribadi dan antarpribadi. Model penilaian INTRAKOG dan ANTARKOG disusun dalam bentuk projective test. Pernyataan dalam projective test dibuat dalam bentuk dilema moral artinya kasus tersebut merupakan kasus tentang moral yang dilematis. Penilaian dan pemberian skornya dilakukan dengan cara melihat alasan yang dikemukakan oleh siswa. Kemudian jawaban tersebut dinilai berdasarkan klasifikasi tahapan moral sesuai pendapat Kohlberg seperti ditunjukkan pada Tabel 1.

Tabel 1. Tingkatan Moral Kognitif

\begin{tabular}{lcl}
\hline $\begin{array}{l}\text { Tingkatan } \\
\text { Moral }\end{array}$ & Skor & Tahapan Moral \\
\hline $\begin{array}{l}\text { Pra- } \\
\text { kovensional }\end{array}$ & 2 & Egosentrik \\
\hline Konvensional & 3 & Persetujuan mayoritas \\
& 4 & Pemelihara aturan sosial \\
\hline Pasca- & 5 & Komitmen kontrak sosial \\
konvensional & 6 & Etis universal \\
\hline
\end{tabular}

Model penilaian keterampilan intrapribadi dan antarpribadi pada aspek afektif disingkat INTRAFEK dan ANTARFEK

Model penilaian ini digunakan untuk mengetahui perasaan diri dan rasa spiritualitas diri. Model penilaian ini dibuat dalam bentuk grading skills yakni berupa sejumlah tingkatan keterampilan yang disusun secara tidak berurutan, dan siswa diminta untuk memilih norma, perasaan, dan perilaku yang paling sesuai dengan kebiasaan yang dilakukan siswa.

Model penilaian keterampilan intrapribadi dan antarpribadi pada aspek psikomotor disingkat INTRATOR dan ANTARTOR

Model penilaian ini digunakan untuk mengetahui performan perilaku siswa sehari-hari. Model penilaian ini dibuat dalam bentuk lembar observasi dengan skala peng- amatan yang bergerak dari belum muncul sampai sudah muncul secara konsisten. Penilaian ini dilakukan oleh guru kelas untuk mengetahui tingkat intensitas perilaku dan sikap siswa sehari-hari.

\section{Validasi Model PKLA-SD}

Validasi isi model PKIA-SD diberikan oleh tiga unsur yakni pakar, praktisi, dan responden. Dari hasil validasi pakar yang meliputi berbagai bidang: psikometri, karakter, psikologi, bahasa, dan metodologi diperoleh saran penyempurnaan draf model PKIA-SD. Kelima pakar juga melakukan penilaian secara kuantitatif terhadap draf model PKIA-SD yang meliputi lima aspek penilaian yakni: (1) petunjuk penilaian, (2) cakupan penilaian, (3) penggunaan bahasa, (4) tata tulis penilaian, dan (5) penilaian secara menyeluruh. Hasil penilaian pakar dianalisis dengan formula Aiken's V dan diperoleh nilai koefisien kesepakatan rater untuk validitas isi sebesar 0,88 . Nilai koefisien ini termasuk tinggi bagi item tersebut. Hal ini berarti item tersebut memiliki validitas isi yang baik dan mendukung isi tes secara keseluruhan.

Berdasarkan masukan dari praktisi, diperoleh saran berupa pengurangan jumlah item model penilaian INTRAKOG dan ANTARKOG dari 30 butir soal menjadi 10 butir soal, dan skala penilaiannya dari 1-4 menjadi 1-6. Alasan pengurangan butir yaitu: (1) untuk mempermudah pembuatan kasus moral dilematis secara tepat, (2) dapat mengukur kemampuan penalaran moral siswa SD pada setiap indikator keterampilan intrapribadi dan antarpribadi, (3) memudahkan dalam melakukan penskoran setiap item, (4) tidak terjadi duplikasi item yang dipergunakan untuk mengukur tahapan penalaran moral anak SD, dan (5) kata-kata yang digunakan lebih operasional untuk mengukur penalaran moral siswa SD, dan (6) memudahkan dalam analisis.

Dari uji keterbacaan model PKIA-SD oleh siswa diperoleh saran untuk perbaikan penggunaan istilah-istilah dan kalimat yang sulit dimengerti oleh siswa. Hal itu perlu disederhanakan agar sesuai dengan tingkat penalaran siswa SD. 


\section{Uji Coba Model PKIA-SD Tahap I}

Uji coba model PKIA-SD dilakukan dalam dua tahap. Uji coba tahap pertama dilakukan pada sampel kecil, yaitu 2 SD yang berjumlah 54 siswa. Penentuan sekolah didasarkan perbedaan budaya pendidikan karakter yang diterapkan pada sekolah tersebut.

Hasil uji coba tahap pertama menunjukkan bahwa keterampilan intrapribadi dan antarpribadi aspek psikomotor siswa lebih baik dibandingkan keterampilan intrapribadi dan antarpribadi aspek kognitif dan afektif. Hal ini membuktikan bahwa pendidikan karakter tidak harus dilakukan secara linier yakni berurutan dari kognitif, afektif, kemudian psikomotor. Oleh karena itu, metode yang tepat digunakan untuk mendidik karakter adalah dengan pendekatan konstruktivistik. Artinya siswa dapat secara bersamaan dilatih untuk berkarakter positif, bahkan dapat dimulai dari metode pembiasaan kemudian baru dilanjutkan dengan metode penalaran terhadap perilaku.

Hasil uji coba ini juga menunjukkan bahwa siswa SD memiliki keterampilan intrapribadi yang rendah pada kemampuan mengelola emosi, mengenali emosi, dan menghargai emosi diri sendiri, sedangkan kemampuan yang paling tinggi adalah kemampuan merasakan rasa spiritualitas diri. Keterampilan antarpribadi siswa SD yang paling rendah adalah kemampuan menghargai pikiran dan perasaan orang lain. Kemampuan yang paling tinggi adalah kemampuan tanggung jawab sosial dan kemampuan untuk bersikap tenggang rasa kepada orang lain.

Hasil analisis validitas konstruk dengan Exploratory Factor Analysis (EFA), dan hasil analisis reliabilitas menggunakan formula Cronbach's Alpha terhadap model PKIA-SD disajikan pada Tabel 2.

Tabel 2. menunjukkan bahwa keenam instrumen model PKIA-SD termasuk kategori memuaskan, dan sebagian besar faktor yang terbentuk adalah unidimensi. Pada model PKIA-SD aspek intrator terdapat dua faktor yang memiliki nilai eigenvalue yang lebih besar dari satu. Namun, faktor yang dipilih hanyalah satu, yakni faktor yang memiliki kedekatan makna dengan variabel yang diukur, dan memiliki nilai varian yang lebih besar dari kedua faktor tersebut.

Tabel 2. Hasil EFA dan Uji Relibilitas

\begin{tabular}{cccc}
\hline $\begin{array}{c}\text { Model } \\
\text { PKIA }\end{array}$ & $\begin{array}{c}\text { KMO } \\
\text { MSA }\end{array}$ & $\begin{array}{c}\text { Nilai } \\
\text { eigenvalue }\end{array}$ & $\begin{array}{c}\text { Relia- } \\
\text { bitas }\end{array}$ \\
\hline Intrakog & 0,869 & 1 faktor & 0,823 \\
Antarkog & 0,872 & 1 faktor & 0,818 \\
Intrafek & 0,938 & 1 faktor & 0,779 \\
Antarfek & 0,937 & 1 faktor & 0,776 \\
Intrator & 0,924 & 2 faktor & 0,775 \\
Antartor & 0,902 & 1 faktor & 0,774 \\
\hline
\end{tabular}

Kemampuan siswa yang sudah baik dalam aspek keterampilan intrapribadi, yaitu kemampuan menghargai dan mengendalikan emosi diri, sedangkan kemampuan siswa yang masih perlu pembinaan adalah kemampuan mengelola dan mengenali emosi diri. Dalam aspek keterampilan antarpribadi, kemampuan siswa yang sudah baik yaitu kemampuan dalam berkomunikasi dengan orang lain, kemampuan bekerja sama, dan kemampuan berempati pada orang lain, sedangkan kemampuan siswa yang masih perlu pembinaan adalah kemampuan dalam bertanggung jawab dan kemampuan menghargai orang lain.

\section{Uji Coba Model PKIA-SD Tahap II}

Uji coba tahap kedua dilakukan pada sampel diperluas, berjumlah 464 siswa berasal dari 15 SD. Penentuan sekolah didasarkan perbedaan budaya sekolah yang beragam dalam pelaksanaan pendidikan karakter.

Uji coba tahap kedua bertujuan untuk mengujicobakan model penilaian yang telah direvisi, baik bahasa, konten, maupun prosedur pelaksanaan. Hal itu sesuai saran yang diperoleh dari hasil uji coba tahap pertama.

Pengujian kecocokan model PKIASD dilakukan dengan menggunakan model pengukuran analisis faktor konfirmatori orde dua (second order confirmatory factor analysis). Ada dua model pengukuran, yaitu: model 
keterampilan intrapribadi (intrapersonal skill) dan model keterampilan antarpribadi (interpersonal skill) yang masing masing keterampilan tersebut memiliki tiga aspek yaitu aspek kognitif, afektif, dan psikomotor.

Berdasarkan hasil second order CFA untuk konstruk keterampilan intrapribadi diperoleh path diagram yang ditampilkan pada Gambar 1. Hasil analisis kecocokan model (goodness of fit statistics (GOF)) untuk konstruk keterampilan intrapribadi (Wijanto, 2008, p.51-58) ditampilkan pada Tabel 3.

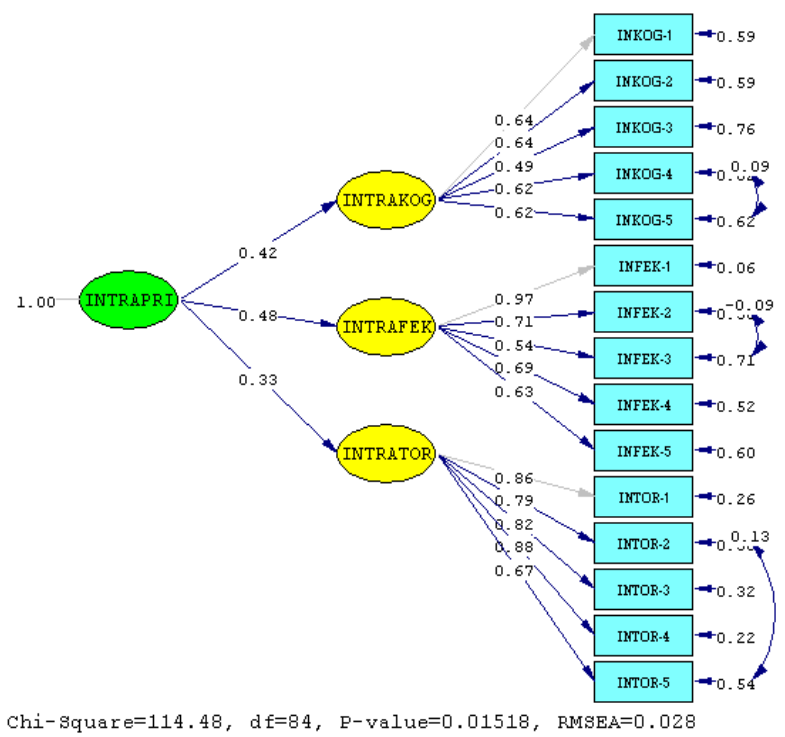

Gambar 1. Hasil Pengujian konstruk Keterampilan Intrapribadi

Tabel 3. Hasil Uji Kecocokan Model Keterampilan Intrapribadi

\begin{tabular}{lccc}
\hline $\begin{array}{c}\text { Kriteria } \\
\text { Goodness of Fit }\end{array}$ & $\begin{array}{c}\text { Tingkat } \\
\text { Kecocokan }\end{array}$ & $\begin{array}{c}\text { Hasil } \\
\text { Estimasi }\end{array}$ & Hasil \\
\hline P-value & $>0,05$ & 0,01518 & Kurang \\
RMSEA & $\leq 0,08$ & 0,028 & Baik \\
RMR & $<0,05$ & 0,041 & Baik \\
NFI & $\geq 0,90$ & 0,97 & Baik \\
NNFI & $\geq 0,90$ & 0,99 & Baik \\
CFI & $\geq 0,90$ & 0,99 & Baik \\
IFI & $\geq 0,90$ & 0,99 & Baik \\
RFI & $\geq 0,90$ & 0,97 & Baik \\
GFI & $\geq 0,90$ & 0,97 & Baik \\
AGFI & $\geq 0,90$ & 0,95 & Baik \\
\hline
\end{tabular}

Sumber: Hasil Analisis LISREL
Dari hasil pengujian kecocokan model tersebut diperoleh 9 ukuran GOF yang menunjukkan kecocokan model yang baik dan 1 ukuran GOF yang menunjukkan kecocokan model yang baik kecuali untuk $p$ value-nya. Dengan demikian, dapat disimpulkan bahwa model pengukuran konstruk keterampilan intrapribadi telah memenuhi ketentuan goodness of fit statistic.

Dari hasil pengujian second order CFA konstruk keterampilan intrapribadi diperoleh 14 nilai variabel teramati (indikator) yang memiliki nilai $t_{\text {hitung }}$ lebih besar dari 1,96 dan nilai koefisien muatan faktor yang distandarkan lebih besar dari 0,50. Dengan demikian dapat disimpulkan bahwa variabel teramati (indikator) tersebut mempunyai validitas yang baik terhadap variabel latennya. Sedangkan 1 nilai variabel teramati (INKOG-3) memiliki nilai $t_{\text {hitung }}$ lebih besar dari 1,96 tetapi nilai koefisien muatan faktor yang distandarkan $(\lambda)$ lebih kecil dari 0,50, sehingga dapat dinyatakan bahwa variabel teramati tersebut (INKOG-3) mempunyai validitas yang cukup terhadap variabel laten kognitif (INTRAKOG). Hal ini dapat disimpulkan bahwa keempatbelas indikator yang digunakan untuk mengukur aspek kognitif, afektif, dan psikomotor pada keterampilan intrapribadi mempunyai validitas yang baik, sedangkan satu indikator mempunyai validitas yang cukup. Hasil Pengujian Second Order CFA konstruk keterampilan intrapribadi ditampilkan pada Tabel 4.

Dari hasil pengujian itu juga diperoleh nilai koefisien reliabilitas komposit (construct reliability, CR) lebih besar dari 0,7 dan nilai koefisien ekstrak varian (variance extracted: VE) lebuh besar dari 0,5 untuk ketiga variabel laten dari konstruk keterampilan intrapribadi. Hal ini berarti reliabilitas semua variabel laten adalah baik. Dengan demikian, dapat disimpulkan bahwa reliabilitas model pengukuran semua variabel laten dari konstruk keterampilan intrapribadi adalah baik.

Berdasarkan pengujian second order CFA untuk konstruk keterampilan antarpribadi diperoleh path diagram yang ditampilkan pada Gambar 2. Hasil pengujian ke- 
cocokan model (goodness of fit statistics) untuk konstruk keterampilan antarpribadi ditampilkan pada Tabel 5.

Tabel 4. Hasil Pengujian Second Order CFA Konstruk Keterampilan Intrapribadi

\begin{tabular}{ccccc}
\hline Variabel & $\begin{array}{c}\text { Stand. } \\
\text { Loading } \\
\end{array}$ & Nilai t & \multicolumn{2}{c}{ Reliabilitas } \\
\cline { 4 - 6 } & Factors & & CR & VE \\
\hline INTRAKOG & & & & \\
INKOG-1 & 0,64 & --- & 0,74 & 0,52 \\
INKOG-2 & 0,64 & 9,74 & & \\
INKOG-3 & 0,49 & 8,15 & & \\
INKOG-4 & 0,62 & 9,06 & & \\
INKOG-5 & 0,62 & 9,04 & & \\
\hline INTRAFEK & & & & \\
INFEK-1 & 0,97 & --- & 0,84 & 0,59 \\
INFEK-2 & 0,71 & 17,96 & & \\
INFEK-3 & 0,54 & 12,48 & & \\
INFEK-4 & 0,69 & 17,61 & & \\
INFEK-5 & 0,63 & 15,46 & & \\
\hline INTRATOR & & & & \\
INTOR-1 & 0,86 & --- & 0,90 & 0,65 \\
INTOR-2 & 0,79 & 20,29 & & \\
INTOR-3 & 0,82 & 21,67 & & \\
INTOR-4 & 0,88 & 24,11 & & \\
INTOR-5 & 0,67 & 16,10 & & \\
\hline
\end{tabular}

Sumber: Hasil Analisis LISREL

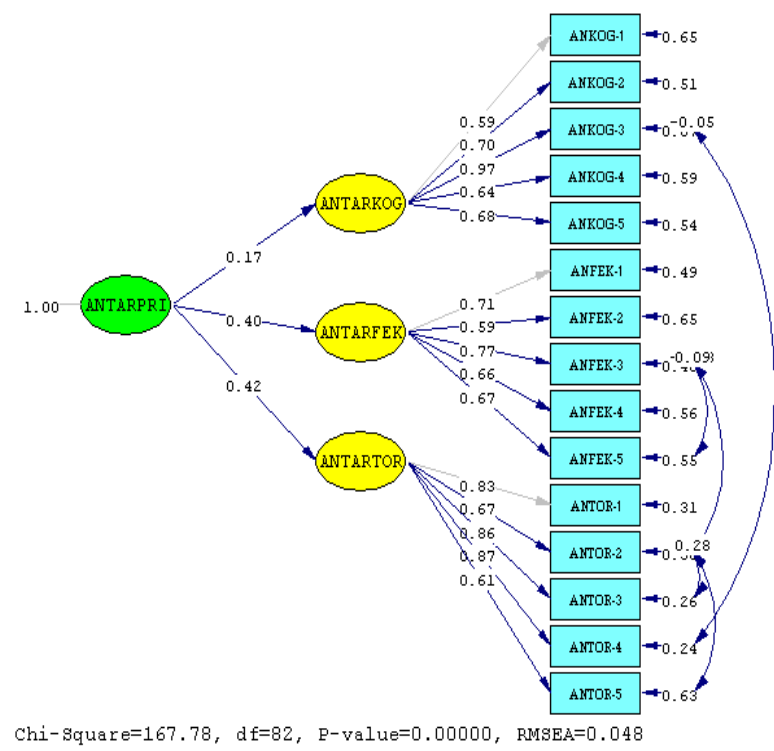

Gambar 2. Hasil Pengujian konstruk Keterampilan Antarpribadi
Dari hasil pengujian kecocokan model tersebut diperoleh 9 ukuran GOF yang menunjukkan kecocokan model yang baik dan 1 ukuran GOF yang menunjukkan kecocokan model yang cukup baik kecuali pada p-value-nya. Dengan demikian, dapat disimpulkan bahwa model pengukuran konstruk keterampilan antarpribadi telah memenuhi ketentuan goodness of fit statistic.

Tabel 5. Hasil Uji Kecocokan Model Keterampilan Antarpribadi

\begin{tabular}{cccc}
$\begin{array}{c}\text { Kriteria } \\
\text { Goodness of Fit }\end{array}$ & $\begin{array}{c}\text { Tingkat } \\
\text { Kecocokan }\end{array}$ & $\begin{array}{c}\text { Hasil } \\
\text { Estimasi }\end{array}$ & Hasil \\
\hline P-value & $>0,05$ & 0,00000 & Kurang \\
RMSEA & $\leq 0,08$ & 0,048 & Baik \\
RMR & $<0,05$ & 0,040 & Baik \\
NFI & $\geq 0,90$ & 0,96 & Baik \\
NNFI & $\geq 0,90$ & 0,97 & Baik \\
CFI & $\geq 0,90$ & 0,98 & Baik \\
IFI & $\geq 0,90$ & 0,98 & Baik \\
RFI & $\geq 0,90$ & 0,95 & Baik \\
GFI & $\geq 0,90$ & 0,95 & Baik \\
AGFI & $\geq 0,90$ & 0,93 & Baik \\
\hline
\end{tabular}

Sumber: Hasil Analisis LISREL

Dari hasil pengujian second order CFA konstruk keterampilan antarpribadi diperoleh 15 nilai variabel teramati (indikator) yang memiliki nilai $t_{\text {hitung }}$ lebih besar dari 1,96 dan nilai koefisien muatan faktor yang distandarkan lebih besar dari 0,50. Dengan demikian dapat disimpulkan bahwa kelima belas variabel teramati (indikator) tersebut mem-punyai validitas yang baik terhadap variabel latennya. Hal ini dapat disimpulkan bahwa semua indikator yang digunakan untuk mengukur aspek kognitif, afektif, dan psikomotor pada keterampilan intrapribadi mempunyai validitas yang baik. Hasil Pengujian Second Order CFA konstruk keterampilan antarpribadi ditampilkan pada Tabel 6.

Dari hasil pengujian itu juga diperoleh nilai koefisien reliabilitas komposit (construct reliability: CR) lebih besar dari 0,7 dan nilai koefisien ekstrak varians (variance extracted: VE) lebuh besar dari 0,5 untuk ketiga variabel laten dari konstruk keterampilan antar- 
pribadi. Hal ini berarti reliabilitas semua variabel laten adalah baik. Dengan demikian, dapat disimpulkan bahwa reliabilitas model pengukuran semua variabel laten dari konstruk keterampilan antarpribadi adalah baik.

Tabel 6. Hasil Pengujian Second Order CFA Konstruk Keterampilan Antarpribadi

\begin{tabular}{|c|c|c|c|c|}
\hline \multirow[t]{2}{*}{ Variabel } & \multirow{2}{*}{$\begin{array}{l}\text { Stand. } \\
\text { Loading } \\
\text { Factors }\end{array}$} & \multirow[t]{2}{*}{ Nilai t } & \multicolumn{2}{|c|}{ Reliabilitas } \\
\hline & & & CR & VE \\
\hline \multicolumn{5}{|l|}{ ANTARKOG } \\
\hline ANKOG-1 & 0,59 & --- & 0,84 & 0,53 \\
\hline ANKOG-2 & 0,70 & 12,30 & & \\
\hline ANKOG-3 & 0,97 & 14,11 & & \\
\hline ANKOG-4 & 0,64 & 11,48 & & \\
\hline ANKOG-5 & 0,68 & 12,01 & & \\
\hline \multicolumn{5}{|l|}{ ANTARFEK } \\
\hline ANFEK-1 & 0,71 & --- & 0,81 & 0,50 \\
\hline ANFEK-2 & 0,59 & 11,49 & & \\
\hline ANFEK-3 & 0,77 & 13,35 & & \\
\hline ANFEK-4 & 0,66 & 12,86 & & \\
\hline ANFEK-5 & 0,67 & 11,57 & & \\
\hline \multicolumn{5}{|l|}{$\overline{\text { ANTARTOR }}$} \\
\hline ANTOR-1 & 0,83 & --- & 0,88 & 0,60 \\
\hline ANTOR-2 & 0,67 & 15,14 & & \\
\hline ANTOR-3 & 0,86 & 21,36 & & \\
\hline ANTOR-4 & 0,87 & 21,69 & & \\
\hline ANTARKOG & 0,61 & 13,66 & & \\
\hline
\end{tabular}

Sumber: Hasil Analisis LISREL

Berdasarkan hasil analisis second order $C F A$ tersebut, maka dapat diketahui bahwa dua model yaitu: (1) model instrumen penilaian keterampilan intrapribadi (INTRAPRI) yang terdiri dari aspek keterampilan intrapribadi kognitif (INTRAKOG), aspek keterampilan intrapribadi afektif (INTRAFEK), aspek keterampilan intrapribadi psikomotor (INTRATOR) dan model (2) instrumen penilaian keterampilan antarpribadi (ANTARPRI) yang terdiri dari aspek keterampilan antarpribadi kognitif (ANTARKOG), aspek keterampilan antarpribadi afektif (ANTARFEK), dan aspek keteram- pilan antarpribadi psikomotor (ANTARTOR) telah memenuhi persyaratan statistik dan dikategorikan sebagai model pengukuran yang cocok ( it $)$. Hal ini berarti model PKIA-SD telah memenuhi goodness of fit statistic, sehingga PKIA-SD dapat dinyatakan sebagai model penilaian yang dapat untuk mendeteksi capaian keterampilan intrapribadi dan antarpribadi dalam pendidikan karakter di Sekolah Dasar.

Dengan demikian, dapat disimpulkan bahwa hasil analisis uji coba tahap II pada keterampilan intrapribadi, kemampuan siswa yang masih rendah, yaitu bersikap inovatif, sehingga diperlukan pembinaan lebih lanjut dari guru kelas melalui pembiasaan dan pembelajaran di sekolah. Pada keterampilan antarpribadi, semua kemampuan siswa sudah baik sehingga guru kelas perlu menjaga pembinaan tersebut melalui pembiasaan dan pembelajaran di sekolah.

\section{Simpulan dan Saran}

Simpulan

Simpulan penelitian ini dapat dirumuskan sebagai berikut: (1) Model penilaian untuk mendeteksi capaian pendidikan karakter di SD selama ini adalah model evaluasi perilaku dan model monitoring akhlak siswa berbasis pelajaran Agama; (2) Kelemahan kedua model penilaian tersebut adalah penilaiannya bersifat mekanik, tidak komprehensif, belum menilai aspek kepribadian, dan tidak melibatkan siswa dalam penilaian; (3) Konstruk model PKIA-SD terdiri dari aspek kognitif, afektif, dan psikomotorik. Penilaian dilakukan komprehensif dengan instrumen berbentuk projective test, rating scale, dan cek list, skala penilaiannya diukur melalui kasus dilema moral, grading skills, dan performance assessment; (4) Instrumen model PKIA-SD telah memenuhi validitas isi dan reliabilitas; (5) Model PKIA-SD dinyatakan valid dan reliabel, dan memenuhi kriteria dalam pengujian kecocokan model (goodness of fit statistics); (6) Prosedur model PKIA-SD diawali dengan menjumlahkan semua hasil penilaian self report siswa pada aspek penalaran dan aspek 
perasaan moral dengan hasil penilaian guru melalui pengamatan aspek perilaku moral selama siswa di sekolah. Hasil penjumlahan ketiga aspek tersebut disusun dalam kategorisasi, sehingga dapat diketahui siswa yang perlu pembinaan dan siswa yang perlu pengayaan karakter; (7) Panduan model PKIA-SD ini dinilai komprehensif, mudah, praktis, dan lengkap oleh para guru selaku pengguna, karena dilengkapi dengan kriteria dan rubrik yang jelas, serta diberikan contoh teknik analisis dan teknik pelaporannya sesuai dengan aturan penilaian dalam Kurikulum 2013.

\section{Saran}

Beberapa saran pemanfaatan model PKIA-SD sebagai berikut: (1) Model PKIASD ini dapat dijadikan sebagai pegangan bagi guru SD untuk mendeteksi capaian keterampilan intrapribadi dan antarpribadi siswa pada aspek kognitif, afektif, dan psikomotor; (2) Penggunaan model PKIA-SD ini dapat mendorong guru lebih objektif dalam melaporkan tingkat capaian keterampilan intrapribadi dan antarpribadi siswa SD kepada pihak-pihak terkait, terutama kepada orang tua yang membutuhkan laporan perkembangan capaian keterampilan anaknya di SD; (3) Model PKIA-SD ini dapat mendorong para guru SD untuk lebih kreatif dan inovatif dalam melakukan kegiatan pembelajaran di kelas, sehingga mampu mendukung peningkatan keterampilan intrapribadi dan antarpribadi siswanya. Penggunaan panduan model PKIA-SD ini telah dilengkapi dengan kriteria dan rubrik yang jelas sehingga dapat membantu guru dalam mengembangkan karakter positif siswa-siswanya.

Sebagai tindak lanjut dari penelitian ini, diharapkan para peneliti atau pihakpihak yang memiliki minat terhadap pengembangan model penilaian keterampilan intrapribadi dan antarpribadi siswa SD, hendaknya penelitian ini dapat dijadikan acuan untuk mengembangkan model penilaian lebih luas lagi, baik dari subjek maupun objeknya, artinya tidak terbatas pada SD kelas tinggi saja, namun dapat diguna- kan untuk acuan pengembangan model penilaian keterampilan intrapribadi dan antarpribadi pada siswa-siswa SD kelas rendah, atau jenjang sekolah di atasnya.

\section{Daftar Pustaka}

Amin, A. (1974). Kitab al-akblak. BeirutLubnan: Dar al-Kitab al-'Araby.

Bar-On, R. (1988). The development of a concept of psychological well-being. Doctoral dissertation: Rhodes University, South Africa.

Bar-On, R.. (1997a). The emotional quotient inventory (EQ-i): a test of emotional intelligence. Toronto, Canada: MultiHelth Systems, Inc.

Bar-On, R.. (1997b). The emotional quotient inventory (EQ-i): technical manual. Toronto. Canada: Multi-Health Systems, Inc.

Bar-On, R.. (2000). Emotional dan social intelligence: Insights from the emotional quotient inventory (EQ-i). In R.Bar-On and J.D.A.Parker (Eds), Handbook of emotional intelligence. San Francisco: Jossey-Bass.

Bar-On, R.. (2005). Emotional intelligence and subjective wellbeing. Manuscript submitted for publication.

Bar-On, R., \& Fund, S. (2004). The impact of emotional and social intelligence on selfpreceived physical belth. Manuscript submitted for publication.

Berkowitz, M.W., Battistich, V.C., \& Bier, M.C. (2002). What works in character education: What is known and what needs to be known. In Nucci, Larry P.\& Narvaez, Darcia. (Eds.). Handbook of moral and character education pp.414-431. New York and London: Routledge Taylon \& Francis Group.

Cunningham, W.G., \& Paula, A.C. (2003). Educational leadership: a problem based approach. Boston: Pearson Education. 
Gardner, H. (1993). Frames of mind: the theory of multiple intelligence. New York: Basic Books.

Gardner, H. (1996). Intelligence: multiple perspectives. Harcourt Brace College. Fort Worth. Tex.

Goleman, D. (1995). Emotional intelligence, why it can matter more than IQ. New York: Bantam Books.

Joreskog, K.G., \& Sorbom, D. (1999). Lisrel 8: User's reference guide. Chicago: Scientific Software International.

Kemendiknas.(2011). Panduan pelaksanaan pendidikan karakter. Jakarta: Balitbang Diknas.

Khilmiyah, A. (2011). Evaluasi implementasi pendidikan karakter pada Sekolah Dasar percontohan pendidikan karakter di kabupaten Bantul. Laporan Penelitian. Yogyakarta: LP3M UMY.

Khilmiyah, A. (2012). Perbandingan keterampilan intrapersonal dan interpersonal siswa Sekolah Dasar Negeri Kasihan Bantul. Jurnal Afkearuna, Vol. 8 No.2 Juli-Desember 2012. ISSN 1693-4040. Yogyakarta: FAI UMY.

Lazear, D. (2000). Pathways of learning: teaching students and parents about multiple intelligences. Arizona: Zephyr.

Lwin, M. (2005). How to multiply your child's intelligence. Terjemahan Christine S. Jakarta: Indeks.
Mant, A. (1997). Intelligent leadership. New South Wales: Allen \& Unwin.

Plomp, T.J. (1997). Educational design: introduction. from Plomp (eds.). Educational \& training system design: introduction. Design of education and training (in Dutch). Utrecht (the Netherlands): Lemma. Netherland. Faculty of Educational Science and Technology, University of Twente.

Wijanto, S. H. (2008). Structural equation modeling dengan Lisrel 8.8 konsep dan tutorial. Jogjakarta: Graha Ilmu.

Zamroni. (2005). Pengembangan sistem penilaian pendidikan yang menerapkan KBK dalam kerangka otonomi daerah. Jurnal Penelitian dan Evaluasi Pendidikan. Vol 2. No.12, Mei 2005, Tahun 11, ISSN 1410-4725. Yogyakarta: HEPI. PPs UNY.

Zuchdi, D. (2010). Humanisasi pendidikan, menemukan kembali pendidikan yang manusiawi. Jakarta: Bumi Aksara.

Zuchdi, D. et.al. (2010). Pengembangan model pendidikan karakter dengan pendekatan komprehensif di Sekolah Dasar terpadu dengan pembelajaran Bahasa Indonesia, IPA dan IPS. Laporan Penelitian Hibah Pascasarjana. Yogyakarta: UNY. 